\title{
PREVALENCE OF ENTERIC BACTERIA PRODUCING TOXINS IN ICE-CREAM AND KAREISH CHEESE IN PORT-SAID CITY MARKETS
}

\author{
GIHAN M.O. MOHAMMED* HANAN A. EL-GHIATY ${ }^{* *}$ and EM. RIAD ${ }^{* * *}$ \\ * Department of Bacteriology, Port Said Laboratory, Egypt. \\ ${ }^{* * *}$ Department of Food Hygiene, Port Said Laboratory, Egypt. \\ **** Department of Bacteriology, Animal Health Institute, Dokki, Giza, Egypt.
}

\section{ABSTRACT}

Received at: 2/12/2012

Accepted: 16/1/2013
The present study estimate the enteric bacteria in ice-cream and Kareish cheese. The study included 120 samples of ice-cream and Kareish cheese (60 of each), collected randomly from supermarkets, shops and street vendors in different districts of Port-Said city. All samples were examined for presence of Enterobacteriaceae spp. (on Violet Red Bile Glucose agar medium). Enterobacteriaceae strains were isolated in a percentage of $60 \%$ and $80 \%$ from group B (unpacked-shop) and group C (unpacked- street vendors) of ice-cream samples respectively, while the Enterobacteriaceae strains were isolated in a percentage of $40 \%$ and $93.3 \%$ from group B (unpacked-shop) and group C (unpacked- street vendors) of Kareish cheese samples respectively. The percentage of isolation of $E$. coli was $13.3 \%$ from group C (unpacked- street vendors) of ice-cream samples, while it was isolated in $6.6 \%$ from group B (unpacked-shop) and 60\% from group C (unpacked- street vendors) of Kareish cheese samples. Salmonella spp. have been isolated in a high percentage (13.3\%) from group C (unpacked- street vendors) of Kareish cheese samples and more than that of ice-cream $(6.6 \%)$. The confirmation of the colonies was done biochemically and were identified up to species level. E.coli isolates from Kareish cheese in group C (unpacked- street vendors) were belonged to Poly(1) O:01, O55:K59 (B5), O124:K72 (B17) and in group B (unpacked-shop) were untyped, while E.coli isolates from ice-cream in group C (unpacked- street vendors) were untyped. Salmonella isolates from ice-cream and Kareish cheese were $S$. Typhimurium and S. paratyphi B. Studying the E.coli and Salmonella isolates for ability to produce toxin by using infant mouse assay was carried out. The isolated serotypes constitute public health hazards to consumers.

Key words: Microbiological examination, dairy products, enteric bacteria producing toxins, Public health.

\section{INTRODUCTION}

Ice-cream and Kareish cheese are considered the most popular Egyptian dairy products. Ice-cream is a milk product, which contains a variety of ingredients in addition to milk, cream and sugar. The richness in nutritive constituents of ice-cream has been realized by all but the production and handling of this food is very complex and associated with problems. Ice-cream is a nutritionally enriched congealed dairy product consumed by all age groups particularly children, during summer (Sharif et al., 2005). Although ice-cream is a nutritious food for human but also an excellent medium for the growth of many microorganisms due to high nutrient value, almost neutral $\mathrm{pH}(\mathrm{pH} \sim 6-7)$ and long storage duration of ice-cream. Contaminated ice-cream causes several outbreaks of gastrointestinal diseases in a number of countries in Asia, Europe and North America (Yaman et al., 2006). Primary sources of microbial contamination of ice-cream include water and raw milk (raw materials), whereas secondary sources include flavoring agents, colouring substances, sanitizer utensils ,handling and from contaminated air during processing (Khalil et al., 2009).

Kareish cheese is one of the most popular soft, fresh, lactic acid, low salt type of cheese in Egypt. Kareish cheese manufacture and handling techniques in Egyptian markets are still primitive and unhygienic. Many contaminants find their way to raw milk, from which they gain access to dairy products (Al-Khatib and Al-Mitwalei, 2009).

Foodborne diseases are common and widespread global problem. Several outbreaks have been reported as a result of eating contaminated dairy food that may look, taste and smell perfectly normal but is in fact contaminated with large number of harmful bacteria (CDC, 2009).

Enterobacteriaceae spp. have been implicated in many cases of food poisoning outbreaks (Koneman et al., 
1994). Escherichia coli is an important organism in the microbiology of the food, besides being involved in foodborne gastroenteritis, it is considered a good indicator of possible fecal contamination of dairy products El-Bagoury and Mosaad, (2002) and Maher et al. (2001).

Salmonella is considered among the most important enteric foodborne pathogen whose presence in the food constitutes a severe health hazard. Many outbreaks of human illness have been associated with the consumption of raw or inadequately heat treated milk or their dairy products (Ellis et al., 1998).

Therefore, this study was carried out to determine the prevalence of Enterobacteriaceae spp. and pathogenic strains in commercially soled ice-creams and Kareish cheese in Port-Said city as well as the ability to produce enterotoxin was studied. Also the public health significance of the isolated microorganisms were discussed.

\section{MATERIALS and METHODS}

\section{1- Collection of samples:}

This study was carried out on 120 dairy products (60 ice-cream and 60 Kareish cheese samples) collected randomly from supermarkets, shops and street vendors in different districts of Port-Said city. All of the samples were collected in sterile plastic bags and transported to the laboratory on ice - box and divided to three groups (A, B and C) for microbiological examination.

\section{2- Preparation of the samples:}

The technique recommended by APHA (1992) was used for samples preparation. Twenty five grams of Kareish cheese samples and $25 \mathrm{ml}$ of ice-cream (after thawed) were aseptically added to $225 \mathrm{ml}$ of Buffered peptone water and then homogenized in a stomacher for $2 \mathrm{~min}$ to form $1: 10$. Ten fold serial dilution were prepared using sterile $0.1 \%$ peptone water.

\section{3- Microbiological examination:}

a- Isolation and identification of Enterobacteriaceae according to FDA (2002).

b- Isolation and identification Salmonella spp. according to ISO (2002). c- Isolation and identification E.coli according to APHA (1992).

d- Serotyping of Salmonella isolates: Colonies were serologically confirmed using diagnostic polyvalent $(\mathrm{O}, \mathrm{H})$ and monovalent Salmonella anti-sera according to (Kauffmann and Das- Kauffmann 2001).

e- Serotyping of E. coli isolates: Colonies were serologically confirmed using diagnostic polyvalent (O, K) anti-sera according Sanderson et al. (1995).

\section{4- Detection of toxin produced by isolates: Enterotoxin assay:}

The ability to produce enterotoxin was assayed by the infant mouse test according to the technique described by (Pai and Mors, 1978) and (Stavric et al., 1992).

\section{1-Preparation of culture filtrate:}

E. coli strains were inoculated into $25 \mathrm{ml}$ of specific media, incubated at room temperature at $22-26^{\circ} \mathrm{C}$, (as well as Salmonella isolates were tested as mentioned above) on a rotatory shaker (200 r.p.m) for 48 hours, centrifuged at $12000 \mathrm{x} \mathrm{g}$ for 10 minutes. The supernatant were filtered through Millipore membrane filter (Pore size $0.22 \mu \mathrm{m}$ ), stored at $-20^{\circ} \mathrm{C}$, till used. A part of the sterile medium was used as a negative control.

\section{2- Infant mouse assay:}

A volume of $0.1 \mathrm{ml}$ of culture filtrate was injected through the abdominal wall into milk-filled stomach of each of 2 mice (for each serotype) which were 2 to 4 days old. Another 2 infant mice were injected by 0.1 $\mathrm{ml}$ saline and were used as negative control. After 4 hours, the mice were killed and the entire intestine was removed. The intestine and the remaining body were weighted to calculate the ratio of (intestine weight) / (remaining body weight). A ratio greater than 0.083 was recorded as positive test for enterotoxin.

\section{RESULTS}

Table 1: Incidence of Enterobacteriaceae in examined ice-cream (60) and Kareish cheese (60) samples.

\begin{tabular}{lllcc}
\hline examined samples & & Type & \multicolumn{2}{c}{ Enterobacteriaceae } \\
\cline { 3 - 5 } Ice-cream & & No. & $\%$ \\
& Group A & $(\mathrm{n}=30)$ & 0 & $0 \%$ \\
\cline { 2 - 5 } & Group B & $(\mathrm{n}=15)$ & 9 & $60 \%$ \\
\cline { 2 - 5 } & Group C & $(\mathrm{n}=15)$ & 12 & $00 \%$ \\
\hline Kareish cheese & Group A & $(\mathrm{n}=30)$ & 0 & 040 \\
\cline { 2 - 5 } & Group B & $(\mathrm{n}=15)$ & 6 & $93.3 \%$ \\
\cline { 2 - 5 } & Group C & $(\mathrm{n}=15)$ & 14 & \\
\hline
\end{tabular}

Group A = Packed (market).

Group B = unpacked (shop).

Group $\mathrm{C}=$ unpacked (street vendors). 
Table 2: Incidence of Enterobacteriaceae strains isolated from the examined ice-cream (60) and Kareish cheese (60) samples.

\begin{tabular}{|c|c|c|c|c|c|c|c|c|c|c|c|c|}
\hline \multirow{3}{*}{$\begin{array}{l}\text { Enterobacteriaceae } \\
\text { Strains }\end{array}$} & \multicolumn{6}{|c|}{ Ice-cream } & \multicolumn{6}{|c|}{ Kareish cheese } \\
\hline & \multicolumn{2}{|c|}{$\begin{array}{c}\text { Group A } \\
n=30\end{array}$} & \multicolumn{2}{|c|}{$\begin{array}{c}\text { Group B } \\
n=15\end{array}$} & \multicolumn{2}{|c|}{$\begin{array}{c}\text { Group C } \\
n=15\end{array}$} & \multicolumn{2}{|c|}{$\begin{array}{c}\text { Group A } \\
n=30\end{array}$} & \multicolumn{2}{|c|}{$\begin{array}{c}\text { Group B } \\
n=15\end{array}$} & \multicolumn{2}{|c|}{$\begin{array}{c}\text { Group C } \\
n=15\end{array}$} \\
\hline & No. & $\%$ & No. & $\%$ & No. & $\%$ & No. & $\%$ & No. & $\%$ & No. & $\%$ \\
\hline E.coli & 0 & $0 \%$ & 0 & $0 \%$ & 2 & $13.3 \%$ & 0 & $0 \%$ & 1 & $6.6 \%$ & 9 & $60 \%$ \\
\hline $\begin{array}{l}\text { Klebsiella } \\
\text { pneumoniae }\end{array}$ & 0 & $0 \%$ & 2 & $13.3 \%$ & 3 & $20 \%$ & 0 & $0 \%$ & 2 & $13.3 \%$ & 1 & $6.6 \%$ \\
\hline Klebsiella oxytoca & 0 & $0 \%$ & 1 & $6.6 \%$ & 2 & $13.3 \%$ & 0 & $0 \%$ & 1 & $6.6 \%$ & 1 & $6.6 \%$ \\
\hline Proteus mirabilis & 0 & $0 \%$ & 6 & $40 \%$ & 4 & $26.6 \%$ & 0 & $0 \%$ & 2 & $13.3 \%$ & 1 & $6.6 \%$ \\
\hline Salmonella sp. & 0 & $0 \%$ & 0 & $0 \%$ & 1 & $6.6 \%$ & 0 & $0 \%$ & 0 & $0 \%$ & 2 & $13.3 \%$ \\
\hline
\end{tabular}

Group A = Packed (market).

Group $\mathrm{B}=$ unpacked (shop).

Group $\mathrm{C}=$ unpacked (street vendors).

Table 3: Serodiagnosis of E.coli and Salmonella isolated from the examined ice-cream (60) and Kareish cheese (60) samples.

\begin{tabular}{|c|c|c|c|c|c|c|}
\hline \multirow{2}{*}{ Types of examined samples } & \multicolumn{3}{|c|}{ Ecoli } & \multicolumn{3}{|c|}{ Salmonella } \\
\hline & $\begin{array}{l}\text { Strain/ Antigenic } \\
\text { structure }\end{array}$ & No. & $\%$ & $\begin{array}{c}\text { Strain / Antigenic } \\
\text { structure }\end{array}$ & No. & $\%$ \\
\hline Ice-cream Group A n=30 & - & 0 & $0 \%$ & - & 0 & $0 \%$ \\
\hline Ice-cream Group B n=15 & - & 0 & $0 \%$ & - & 0 & $0 \%$ \\
\hline Ice-cream Group C n=15 & Untyped & 2 & $13.3 \%$ & $\begin{array}{c}B S . \text { paratyphi } \\
\mathrm{O}: 1,4,(5), 12 \\
\mathrm{H}_{1}: \mathrm{b}, \mathrm{H}_{2}: 1,2\end{array}$ & 1 & $6.6 \%$ \\
\hline Kareish cheese Group A n=30 & - & 0 & $0 \%$ & - & 0 & $0 \%$ \\
\hline Kareish cheese Group B n=15 & untyped & 1 & $6.6 \%$ & - & 0 & $0 \%$ \\
\hline \multirow[t]{4}{*}{ Kareish cheese Group C n $=15$} & Untyped & 3 & $20 \%$ & $\begin{array}{c}B S . \text { paratyphi } \\
\mathrm{O}: 1,4,(5), 12 \\
\mathrm{H}_{1}: \mathrm{b}, \mathrm{H}_{2}: 1,2\end{array}$ & 1 & $6.6 \%$ \\
\hline & Poly(1)O:01 & 3 & $20 \%$ & S. Typhimurium & 1 & $6.6 \%$ \\
\hline & O55:K59 (B5) & 2 & $13.3 \%$ & $\mathrm{O}: 1,4,(5), 12$ & & \\
\hline & O124:K72 (B17) & 1 & $6.6 \%$ & $\mathrm{H}_{1}: \mathrm{i}, \mathrm{H}_{2}: 1,2$ & & \\
\hline
\end{tabular}

Group A = Packed (market).

Group $B=$ unpacked (shop).

Group $\mathrm{C}=$ unpacked (street vendors).

Table 4: Detection of enterotoxin producing E. coli and Salmonella strains isolated from the examined icecream (60) and Kareish cheese (60) samples using infant mouse assay.

\begin{tabular}{|c|c|c|c|c|c|c|c|c|c|c|}
\hline \multirow[t]{2}{*}{$\begin{array}{l}\text { Types of } \\
\text { examined samples }\end{array}$} & \multirow{2}{*}{$\frac{\text { E.coli }}{\text { No. }}$} & \multicolumn{2}{|c|}{$\begin{array}{c}\text { Positive of } \\
\text { enterotoxigenic } \\
\text { E. coli }\end{array}$} & \multirow[t]{2}{*}{$\begin{array}{l}\mathrm{G} / \mathrm{W} \\
\text { ratio } \\
\text { mean }\end{array}$} & Salmonella & \multicolumn{2}{|c|}{$\begin{array}{l}\text { Positive of } \\
\text { enterotoxigenic } \\
\text { Salmonella }\end{array}$} & \multirow[t]{2}{*}{$\begin{array}{l}\mathrm{G} / \mathrm{W} \\
\text { ratio } \\
\text { mean }\end{array}$} & \multirow{2}{*}{$\begin{array}{l}\text { Control } \\
\text { No. } \\
\end{array}$} & \multirow{3}{*}{$\begin{array}{l}\mathrm{G} / \mathrm{W} \\
\text { ratio } \\
\text { mean }\end{array}$} \\
\hline & & No. & $\%$ & & No. & No. & $\%$ & & & \\
\hline $\begin{array}{l}\text { Ice-cream } \\
\text { Group } C \mathrm{n}=15\end{array}$ & 2 & 1 & $50 \%$ & 0.084 & 1 & 0 & $0 \%$ & 0.079 & \multirow{3}{*}{2} & \\
\hline $\begin{array}{l}\text { Kareish cheese } \\
\text { Group B } n=15\end{array}$ & 1 & 0 & $0 \%$ & 0.079 & 0 & 0 & $0 \%$ & - & & \multirow{2}{*}{0.079} \\
\hline $\begin{array}{l}\text { Kareish cheese } \\
\text { Group C } n=15\end{array}$ & 9 & 5 & $55.5 \%$ & 0.086 & 2 & 0 & $0 \%$ & 0.079 & & \\
\hline
\end{tabular}

Group B= unpacked (shop).

Group $\mathrm{C}=$ unpacked (street vendors). 


\section{DISCUSSION}

The International Commission on Microbiological Specification for foods has classified cheese and icecream as a high risk potential hazard (Abou-Donia, 1984). This could be confirmed by its implication in several outbreaks of food poisoning (Bryan, 1988). The microbiological qualities of packed and unpacked ice-cream and Kareish cheese are shown in Table 1. Current results revealed that Enterobacteriaceae were isolated in a high percentage $93.3 \%$ and $80 \%$ of Kareish cheese and ice-cream samples in group C (unpacked - street vendors) respectively than those isolated from (unpacked shop). The results nearly agree with those obtained by Fadel and Jehan (2009) who isolated Enterobacteriaceae in $100 \%$ and $75 \%$ of Kareish cheese and ice-cream samples respectively. Enterobacteriaceae are distributed worldwide. The presence in large number indicates faecal contamination of food, inadequate processing and post- processing contamination Koneman et al. (1994).

Table 2, showed the incidence of Enterobacteriaceae strains from examined ice-cream and Kareish cheese (unpacked-shop) and (unpacked - street vendors). E.coli (0\%-13.3\%), Klebsiella pneumoniae (13.3\%$20 \%)$, Klebsiella oxytoca (6.6\%-13.3\%), Proteus mirabilis (40\%-26.6\%) and Salmonella spp. (0\%- 6.6\%) from examined ice-cream (unpackedshop) and (unpacked - street vendors) respectively. These results agree with that recorded by Khalil et al. (2009) as they could isolate E. coli (100\%), Klebsiella $(85 \%)$, proteus $(45 \%)$ and Salmonella spp. (15\%) from ice- cream samples who explained that many opportunities exist for contamination of icecream from the hands of workers and other equipments. During processing of ice-cream. Furthermore, the microbiological quality of icecream during retail marketing mainly depends upon the post production, handling of the product as well as efficiency and sanitary conditions during storage. The lack of efficient storage under warm tropical climatic conditions causes a chance of temperature abuse during transport and distribution of ice-cream Kanbakna et al. (2004). Also E.coli (6.6\%-60\%), Klebsiella pneumoniae (13.3\%- 6.6\%), Klebsiella oxytoca (6.6\%-6.6\%), Proteus mirabilis (13.3\%$6.6 \%)$ and Salmonella spp. (0\%- 13.3\%) from examined Kareish cheese (unpacked-shop) and (unpacked - street vendors) respectively. These results agree with that recorded by Fadel and Jehan (2009) as they could isolate E. coli $(44.4 \%)$, and Klebsiella pneumoniae (11.1\%) only from Kareish cheese samples, while they couldn't detect Klebsiella oxytoca and Proteus mirabilis. El-Prince and Hussein (2000), Khalil et al. (2009) and Amin, (2004) as they could isolate Salmonella spp. from ice-cream samples, while Delia et al. (1980) failed to detect
Salmonella. On the contrary, There is no much available data about the prevalence of Salmonella in Kareish cheese, however, (Abd El- Atty and Meshref 2007; El-Kosi, 2001 and Amin, 2004) detected Salmonella spp. in (4\%), (3.33\%) and (10\%) in Kareish cheese respectively. On the other hand (Bahout and Moustafa 2006; El-Kholy 1989 and Fadel and Jehan 2009) failed to recover Salmonella from Kareish cheese samples. presence of some pathogenic microorganisms especially Salmonella due to using raw milk in the production accompanied by improper sanitary practices during manufacturing, handling and selling. The difference between our results and the previous studies may be attributed to sampling techniques, sources of sampling, handling of samples and types of media. Because of the public health hazards of these microorganisms, the Egyptian standards for ice- cream and Kareish cheese proposed that E. coli and Salmonella spp. should not be detected in the ice-cream and Kareish cheese (Ministry of Industry and Technological Development, 1993; Ministry of Industry and Technological Development, 2000) (Table 2).

Contamination represents a public health risk due to the possible presence and transmission of pathogens. The mode of transmission of all these bacteria is fecaloral route and or via common house flies. The results suggested negligence such as poor sanitation during the preparation and/or storage of these products. These include the observed dirty premises and utensils used, the use of bare hands in preparing the products (personal communication with the handlers) (Fadel and Jehan 2009). In this study the most important genera Escherichia coli and Salmonella spp.

Table 3, showed the E.coli could be isolated and identified as $13.3 \%$ untyped from ice-cream in group C, and E.coli which isolated from Kareish cheese were identified as $6.6 \%$ untyped in group B, while in group C E.coli strains were identified as $20 \%$ untyped, $20 \%$ of Poly(1) O:01, 13.3\% of O55:K59 (B5) and 6.6\% of O124:K72 (B17) (Hassan et al., 2009). Salmonella spp. were identified as $S$. paratyphi $B$ from ice-cream in group C (unpacked- street vendors), But Salmonella isolated from Kareish cheese samples were $S$. Typhimurium and $S$. paratyphi B. in group C (unpacked- street vendors) (Amal and Mohammed 2003; Ekbal and Azza 2006 and Mahmoud, 2004). The production of enterotoxin of the isolated $E$. coli and Salmonella spp. from ice-cream and Kareish cheese samples were shown in Table (4). E. coli strains isolated from ice-cream samples in group B (unpacked-shop) and group C (unpacked -street vendors) in a percent of (50\%), (55.5\%) were enterotoxin producing and caused accumulation of fluids in the intestinal tract of the injected infant mice respectively. While Salmonella isolated in this study were unable to produce enterotoxin (Stavric et al., 1992 and Wallis et al., 1986). 
In conclusion, our results revealed out that Egyptian Kareish cheese and ice cream products sold in PortSaid city markets and street-vendors are contaminated with Enterobacteriaceae sp. These isolates constitute public health hazards to consumers. Periodical examination of dairy products to ensure safety for consumers must be practiced. The isolation of bacterial pathogens from dairy products reflects bad hygienic standards and necessitates regular inspection of them for prevalence of foodborne pathogens. Adoption of reward and punishment policy may help to improve their hygienic standards. Overall, good quality raw materials used in product processing, adoption of Good Manufactured Practices (GMP) and strict personal hygiene are the way to ensure safety and high quality dairy products.

\section{REFERENCE}

Abou-Donia, S.A. (1984): Egyptian fresh fermented milk products. New Zeal. J. Dairy Sci., (19): 7-18.

Abd El-Atty, N.S. and Meshref, A.M.S. (2007): Prevalence of Salmonella and E.coli $\mathrm{O} 157$ in some foods. Bs. Vet. Med. J., $5^{\text {th }}$ Scientific Conference: $73-78$.

Al-Khatib, I.A. and Al-Mitwalei, S.M. (2009): Microbiological quality and sample collection policy for dairy products in Ramalla and AlBireh district, Palestine East Mediterranean Health J., 15: 709-716.

Amal, S.M.S. and Mohammed, S. (2003): Prevalence of some zoonotic enteropathogenic bacteria in ice-cream. $2^{\text {nd }}$ Inter. Congress of Food Hygiene and Human Health 21-23.

Amin, Walaa, F. (2004): Some studies on Salmonella species in milk and some milk products in Assiut. M.V.Sc. Thesis, Faculty of Veterinary Medicine, Assiut University.

"APHA', American Public Health Assoc. (1992): Compendium of Methods for the Microbiological Examination of Foods. APHA, Washington, DC.

Bahout, A.A. and Moustafa, A.H. (2006): Occurrence of some microorganisms in relation to public health in Kareish cheese. Assiut Vet. Med. J., 52: 111.

Bryan, F.L. (1988): Risks associated with vehicles of foodborne pathogens and toxins. J. Food Protect., 51: 498-508.

Centers for Disease Control and Prevention (CDC): (2009): Surveillance for foodborne disease outbreak, United States, 2006. Morbidity Mortality Weekly Rep., 58: 609-615.

Delia, S.; Mauro, A. and Donia, D. (1980): Application of the Ministerial Ordinance of 11 October 1978 on ice-cream in the city of Messina. Italian Rivista della Societa Italiana di Scienza dell' Alimentazione, 9( 6): 437-440.
Ekbal, M.A.I and Azza, M.K.S. (2006): Diarrhoeagenic E.coli in Kareish cheese manufactured by different methods with special reference to $E$. coli O157: H 7. Minufiya. Vet. Med. J. 4(1): $169-178$. The $4^{\text {th }}$ Scientific Conference.

El-Bagoury, A.M. and Mosaad, A.A. (2002): Incidence of Salmonella and Escherichia coli in Kareish cheese with special reference to heat stable enterotoxin producing Escherichia coli using polymerase chain reaction. Minufiya Vet. J., 2: 59-68.

El-Kholy, A.M. (1989): Enterobacteriaceae in Egyptian soft cheese and their public health significance. Assiut Vet. Med. J., 21: 42, 70-75.

El-Kosi, O.H.R. (2001): Occurrence of some enteric pathogens and their indicators in some Egyptian raw milk products. Assiut Vet. Med. J., 45 (89): 48-61.

Ellis, A.; Preston, M.; Borczky, A.; Miller, B. and Stone, P. (1998): A community outbreak of Salmonella berta associated with a soft cheese product. Epidemiol. Infect., 120: 29-35.

El-Prince, E. and Hussein, A.A. (2000): Occurrence of Enterobacteriaceae in ice-cream with special reference to Salmonella species. Assiut Vet. Med. J., 45(89): 104-116.

Fadel, H.M. and Jehan, I. (2009): Prevalence and significance of Staphylococcus aureus and Enterobacteriaceae species in selected dairy products and handlers. Int. J. of Dairy Sci., 4 (3): 100-108.

FDA (2002): U.S. Food and Drug Administration Bacteriological Analytical Manual. Center for Food Safety and Applied Nutrition, Ch., 4.

Hassan, H.F.; Noseir, S.M. and Soultan, H.M. (2009): Prevalence of enteric bacteria in ice-cream in Giza Governorate. Assiut Veterinary Medical Journal 55 (121): 136-142.

ISO (2002): Microbiology of food and animal feeding stuffs- Horizontal method for detection of Salmonella spp. ISO 6579 Organisation for Standardization.

Kanbakna, J.; Con, A.N. and Ayor, A. (2004): Determination of microbiological contamination sources during ice-cream production in Denizli, Turkey. Food Control, 15: 463-470.

Kauffmann, F. and Das-Kauffmann, W. (2001): Antigenic formulas of Salmonella serovars WHO co-operating center for reference and research on Salmonella.8 ed, cited by Popoff, M.Y., paris, France.

Khalil, A.; Azhar, H.; Imran, Mudassier, A.Q. and Wajid, Hussain (2009): Microbiological quality of ice-cream sold in Gilgit town. Pakistan Journal of Nutrition 8 (9): 1397-1400.

Koneman, W.E.; Allen, S.D.; Janda, W.M.; Schrecken Berger, P.C. and Winn, W. (1994): Introduction to Diagnostic Microbiology. Lippincott Publishers, Philadelphia, USA. 
Maher, M.M.; Jordan, K.N.; Upton, M.E. and Coffey, A. (2001): Growth and survival of E. coli O157:H7 during the manufacture and ripening of a smear-ripened cheese produced from raw milk. J. Appl. Microbiol., 90: 201-207.

Mahmoud, F.M. (2004): Studies of Escherichia coli O157:H7 in milk and some milk products Ph.D. Thesis, Faculty of Veterinary Medicine, Assiut University.

Ministry of Industry and Technological Development (1993): The Egyptian standards No. 1185 for Ice- cream. Egyptian Organization for Standardization and Quality Control.

Ministry of Industry and Technological Development (2000): The Egyptian standards No. 1008 for Kareish cheese. Egyptian Organization for Standardization and Quality Control.

Pai, C.H. and Mors, V. (1978): Production of enterotoxin by Yersinia enterocolitica. Infect. Immun., 15(3): 908-911.

Sanderson, M.W.; Gay, J.M.; Hancock, D.D.; Gay, C. C.; Fox, L.K. and Besser, T.E. (1995): Sensitivity of Bacteriologic Culture for
Detection of Escherichia coli O157:H7 in Bovine Feces J. Of Clinic. Microbiol., 33(10): 2616-2619.

Sharif, N.; Ghanghesh, K.S.; Gnan, Y.A.S. and Rahouma, A. (2005): Bacteriological quality of ice-cream in Tripoli-Libya. Food Control, 17: 637-641.

Stavric, S.; Buchanan, B. and Speirs, J. (1992): Comparison of a competitive enzyme immunoassay kit and the infant mouse assay for detecting Escherichia coli heat-stable enterotoxin. Letters in Applied Microbiology 14(2): 47-50.

Wallis, T.S.; Starkey, W.G.; Stephen, J.; Haddon, S.J.; Osborne, M.P. and Candyt, D.C.A. (1986): Enterotoxin production by Salmonella Typhimurium strains of different virulence. J. Med. Microbio1., 21: 19-23

Yaman, H.; Elmali, M.; Ulukanli, Z.; Tuzcu, M. and Genctave, K. (2006): Microbial quality of icecream sold openly by retail outlets in Turkey. Revue. Med. Vet., 157: 457-462.

\footnotetext{
مدى تواجد الميكروبات المعوية المنتجة للسموم في الأيس كريم والجبن القريش بأسواق مدينة بورسعيد جيهان محمد عمر محد ، حنان عباس الغياتى ، عماد مختار رياض

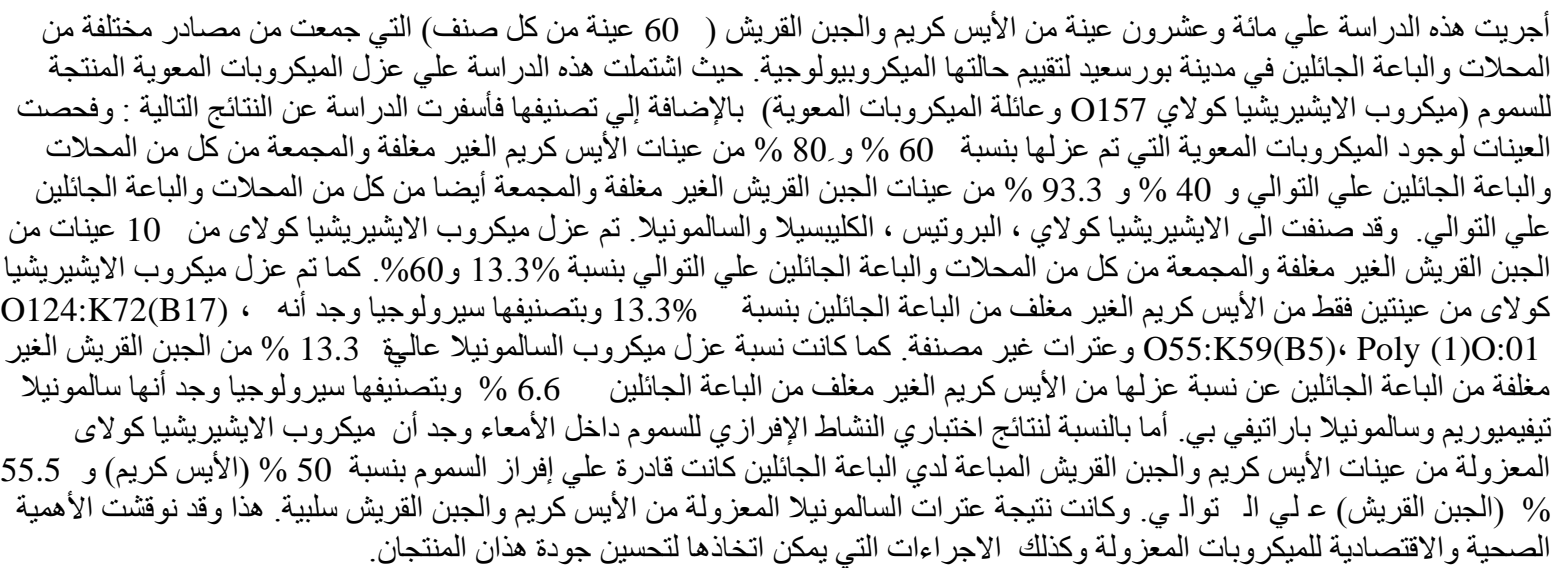

